\title{
Multigenerational Employees: Strategies for Effective Management Rida Ashraf*
}

Department of Business Administration, Near East University, Cyprus

\section{Introduction}

This article highlights one of the biggest challenges that leaders will be facing in managing an employee age profile which could range from 18 to 80 . Traditional Generation, Baby Boomer and Generation X were discussed in this paper. Regarding the behavior, attitude, characteristic, attitude and mentality of the people in the range of age before 1940 to 1980 were taken into consideration. This article also covers the personal behaviors and perspectives of these generations like family commitments, problems and showing the daily routine which includes leisure activities and view of work values.

Here, three generations are described, generational differences and similarities are acknowledged, and implications for employers are discussed.

In the end of this article we can see some leadership practices where he shows his belief that if leader expect people to achieve, they do. Whereas, it is difficult to manage people with different age group which possesses different experiences and family back ground.

\section{The Traditional Generation}

This generation is supposed to be the oldest generation on work place because the people them have been almost retired from their workplaces. The traditional generation is considered as matures, the silent, and the greatest generation, this generation includes individuals born before 1945. Their decisions based on their past experiences. This generation knows to respect others as they like formality and a top down chain of command [1].

This generation knows how to give respect and how to be loyal with people and work. They are natural leaders possesses good communication skills and are obedient. This generation understands the importance of the back bone of the family, so motivating them to be a group leader could be a good and fruitful decision. Members of this generation have also been characterized as loyal workers, highly dedicated, averse to risk and strongly committed toward teamwork and collaboration. They can also be described as having good communication skills, and as the most affluent elderly population in the U.S., due to their tendency to save and conserve [2].

\section{The Baby Boom Generation}

This age group is called as the Baby Boom, because of the extra seventeen million babies born during that period comparative to preceding survey statistics [3]. The range of this age group is between 1943 and 1965. Boomers were raised to esteem power figures, but as they witnessed their faults, cultured not to "belief anyone over 30" [4]. This generation is grew up by the sense that they have the power to change the world as they grew up in an era of "prosperity and optimism, have equated work by means of confidence, giving and individual completion" [5]. The oldest Baby Boomers turned 71 in 2017, and as an in one piece, this cohort is now in the average to late part of their careers.

Workaholic trend was started by this age group; (The National Oceanographic and Atmospheric Association Office of Diversity, 2006 $[6,7])$ believe (d) in paying their duty and gradually promotion $[8,9]$.
They are confident to complete their tasks (www.valueoptions.com), and don't feel good by constant feedback (The National Oceanographic and Atmospheric Association Office of Diversity, [10]), even though they desire that their achievements should be recognized.

\section{Generation X}

Generation $\mathrm{X}$ was also call the baby bust generation, because of its small volume virtual to the generation that preceded it, the Baby Boom generation. The term Generation X spread into popular parlance following the publication of Douglas Coupland's book about a generation of individuals who would come of age at the end of the $20^{\text {th }}$ century. The segment of this generation is between 1968 and 1979. People of Generation X [Hereinafter Xers] are the offspring of grown-up boomers, who grew up in the age of economic, domestic and communal anxiety. They witnessed their parents get laid off and the take a rain check of the American universal authority. They grew up with a heavy job marketplace, corporate downsizing, and partial gross mobility, and are the earliest persons predicted to earn less than their parents did.

As compared to last generation they are more self-determining, sovereign and self-reliant having full-fledged up as latchkey kids. For their employers they are not overly loyal [8-10], while they are strong enough towards their family and friends. They give importance to 4 Generational differences in the administrative center continuous learning and skill development. Generation X contains strong technical skills, As compared to Boomers they are more unique, they preferred to teamwork.

\section{Bridging the Generation Gap}

In the human race through an increasingly assorted staff, the bang of the generational gap surrounded by coworkers is one quarter of multiplicity that is often ignored and underestimated.

In view of the fact that there are so many unlike generations engaged in today's staff, there may not be much of an overall generational gap in the staff as a whole, but the generational gap between two people who work together daily may be considerable.

Earlier than identifying how to bridge the gap, however, it is essential to be aware of why it is very important. Most of us pay out a considerable percentage of our time at work, so we might as well make it pleasurable. As a replacement for of relying on stereotypes and generalizations, we should take time to understand our coworkers.

*Corresponding author: Rida Ashraf, Department of Business Administration Near East University, Cyprus, Tel: 0533862 9221; E-mail: ashrafrida43@gmail.com

Received May 29, 2018; Accepted June 18, 2018; Published June 22, 2018

Citation: Ashraf R (2018) Multigenerational Employees: Strategies for Effective Management. Int J Econ Manag Sci 7: 528. doi: 10.4172/2162-6359.1000528

Copyright: (c) 2018 Ashraf R. This is an open-access article distributed under the terms of the Creative Commons Attribution License, which permits unrestricted use, distribution, and reproduction in any medium, provided the original author and source are credited. 


\begin{tabular}{|c|c|c|c|}
\hline & Traditionalists & Baby Boomers \\
\hline Behaviour & Follows the rules & Challenges rules \\
\hline Training & Learns the hard way & Preferred in moderation way \\
\hline Learning style & Classroom & Facilitated \\
\hline Communication & Top-down & Guarded \\
\hline Problem solving & Hierarchical & Horizontal \\
\hline Lecision making & Seeks approval & Team informed \\
\hline Feedback & Command and control & Unilateral \\
\hline
\end{tabular}

Table 1: Generational perceptions on workplace situations [1].

By showing value, building trust and communicating clearly with coworkers, you will be able to work together with your coworkers more efficiently. This will also foster a positive work environment, making the workplace a more enjoyable place to be. While the generational gap will remain, these steps will help bridge that gap, making a stronger, more integrated workers (Table 1).

\section{Five Techniques for Managing Generational Differences}

The National Conference of Bar Foundations provides an obvious aim to center of attention on at what time supervision generational differences: to expose the actions, situation, principles, and behaviors that build each cohort distinctive!

1) Focus on goals and set clear expectations: Every age group approaches their effort in a different way, all on condition that strengths the other does not hold. An obvious goal and prospect puts every age group on a smooth on stage ground. No need for micro organization presently set the objective and belief.

2) Mentoring and Inclusion Hearten each generation to mentor the other. They all grant special strengths, experiences and awareness of today's machinery. Addition helps to use person's differences as power to make the most of results. In accumulation, most employees' value being built-in opposed to prohibit. Inclusion equals teamwork. Teamwork leads to achieving consequences more rapidly.

3) Break the bonds of tradition If nearby is an improved way to do impressive, take the idea. Even though all generations may be ingredient of the team, the right idea should always be taken. Tradition would tell you to get the point of view of the majority senior in the room. Mistaken, pleasing the view of the older most individual in the span when a better one is presenting may sound lead you to slower or no movement.

4) Show employees the future Tell them where the business is going, how they able-bodied in, and how to get ready. Cheering profession setting up for those with a figure of being in advance, and sequestration scheduling for persons getting ready for, it will assist to engage people in the here and now, and the extensive period potential. People are inclined to effort harder to attain the organizations goals if they appreciate how it leads them on a trail to their skilled goals.

5) Encourage balance Human resources of every age consign a high value on harmonizing their work and private lives. However, depending on their generational traditions, balance will look different. Exit work previous to the offspring come home, captivating full weeks or a month for a break, stretchy work hours, and operational from home is all preferences of the diverse age groups. Asking workforce what they wish in regards to maintaining a stability of job and existence will help you supervise the generational desires, eventually most important to happier recruits working hard to attain the businesses goals.
These five techniques endow with a behavioral approach to managing the generational differences. Since a Managerial Behavior administration perspective, numerous issues can be exaggerated by generational differences: Revenue, Employment, Self-esteem, Team structure Communication, and the success of Rewards, Response and at last achieving Secretarial objectives. Captivating time to realize, and classify how you will supervise these differences will be the factual pointer of achievement in the days to approach.

\section{Motivational Levels}

\section{For traditionalist}

This generation favors hierarchical or standing structures that suggest an obvious course to endorsement. In return, they suggest faithfulness and individual surrender. It's not strange for Traditionalists to stay devoted to presently one or two companies throughout an era.

Practicality took origin in the turbulent financial period and have lead Traditionalists to be ambitious by steadiness, opportunities that facilitate reserved with more safety or elasticity and traditional examine and possession awards such as plaques or certificates.

\section{For baby boomer}

This generation could be better motivated for planning and designing something big for the organization as they possess the quality of seeking big vision. As they are sensitive to feedback, team oriented and avoid conflicts [11].

\section{For Generation X}

Give them clear objectives and goals and let them question the experts and/or authorities, provide them with an environment where they can be independent; with very little corporate structure and rigidity, Encourage them with the prospect of the latest technological advances. As they are creative and confident too they know how to bring reward.

In wrapping up, I'd akin to circumstances that we are still commerce with community, and that we shouldn't simply envelope them into categories. This piece of writing will just give you a "common" image of all generation's individuality; on the other hand, it will not truthfully put in the picture you what every human being will do or is skilled of doing. As managers and HR practitioners, it is still our profession to discover the uniqueness of our teammates and utilize this to deal with them.

\section{References}

1. Kersten D (2002) Today's generations face new communication gaps Retrieved April 15, 2008

2. Jenkins $J$ (2007) Leading the four generations at work. Retrieved April 15 , 2008. 
Citation: Ashraf R (2018) Multigenerational Employees: Strategies for Effective Management. Int J Econ Manag Sci 7: 528. doi: 10.4172/21626359.1000528

Page 3 of 3

3. O'Bannon G (2001) Managing our future: The generation $X$ factor. Public Personnel Management 30: 95-109.

4. Karp H, Fuller C, Sirias D (2002) Bridging the boomer Xer gap. Creating authentic teams for high performance at work. Palo Alto, CA: Davies Black Publishing.

5. Yang SM, Guy ME (2006) GenXers versus boomers: Work motivators and anamgement implications. Public Performance \& Management Review 29: 267-284.

6. Glass A (2007) Understanding generational differences for competitive success. Industrial and Commercial Training 39: 98-103.

7. Zemke R, Raines C, Filipczak B (1999) Generations at work: Managing the clash of veterans, boomers, Xers, and nexters in your workplace. New York: AMACOM.

8. Bova B, Kroth M (2001) Workplace learning and generation X. Journal of Workplace Learning 13: 57-65.

9. Rath D (1999) Bridging the generation gap. InfoWorld 21: 84

10. The National Oceanographic and Atmospheric Association Office of Diversity (2006). Tips to improve the interaction among the generations: Traditionalists, boomers, X'ers and nexters. Retrieved April 15, 2008.

11. Quinn $P$ (2010) A Multigenerational Perspective on Employee Communication. Risk Management 57: 34. 